\section{Aquaculture}

Vol. 253, Issues 1-4 , 31 March 2006, Pages 25-38

http://dx.doi.org/10.1016/j.aquaculture.2005.03.047

(c) 2005 Elsevier B.V. All rights reserved
Archimer, archive institutionnelle de l'Ifremer http://www.ifremer.fr/docelec/

\title{
Molecular identification of Vibrio tapetis, the causative agent of the brown ring disease of Ruditapes philippinarum
}

\author{
Christine Paillard ${ }^{\mathrm{a}, *}$, Sabrina Gausson ${ }^{\mathrm{a}}$, Jean Louis Nicolas ${ }^{\mathrm{c}}$, \\ Jean Paul le Pennec ${ }^{b}$ and Dominique Haras ${ }^{b}$
}

\begin{abstract}
aLaboratoire des sciences de l'environnement marin, UMR 6539, Institut Universitaire Européen de la Mer, Université de Bretagne Occidentale, 29280 Plouzané, France

${ }^{\mathrm{b}}$ Laboratoire de Biotechnologie et Chimie Marines, EA 3884, Université de Bretagne-Sud, BP 92116, 56321 Lorient, France

${ }^{\mathrm{C}}$ Laboratoire de physiologie des invertébrés, IFREMER-Brest, DRV/RA/PI 29280 Plouzané, France

*: Corresponding author : Tel.: +33 298498650; fax: 33 298498645; email : paillard@univ-brest.fr
\end{abstract}

\begin{abstract}
:
Vibrio tapetis is the marine bacterium responsible for the brown ring disease (BRD) affecting the manila clam, Ruditapes philippinarum. Identification of $V$. tapetis has been previously performed using biochemical criteria and serological procedures. All of these methods are time consuming and illadapted to individual screening. This study describes an oligonucleotidic probe (Vt446) and two PCR primers, deduced from the $16 \mathrm{~S}$ rDNA sequence, allowing a fast and specific $V$. tapetis identification using dot blot hybridisation and species-specific primed PCR (SSP-PCR). The probe and primers have been tested on 60 strains, including referenced Vibrio sp., Gram negative and positive bacteria, marine bacteria samples and isolated clam bacteria. For all the $19 \mathrm{~V}$. tapetis strains, the results of PCR assays consistently corroborated those of the agglutination tests. The detection limit was estimated to be $10^{2} \mathrm{CFU} \mathrm{\textrm {ml } ^ { - 1 }}$. The SSP-PCR method has resulted in $V$. tapetis detection in larvae, in diseased clams, and in asymptomatic broodstock clams that later developed BRD. In conclusion, the two SSP-PCR primers were useful for direct and fast identification of $V$. tapetis strains isolated in clams, and are well suited for the screening of individual R. philippinarum broodstock clams and larvae from the hatchery.
\end{abstract}

Keywords: Diagnostic; Detection; Bivalve; Vibriosis; SSP-PCR; DOT-BLOT hybridisation 


\section{Introduction}

Bacteria (mainly vibrios) are often associated with larval bivalve mortalities (For reviews : McGladdery 1999, Sindermann 1990 and Paillard et al, 2004a). Few bacteria induce specific diseases in adults, therefore the etiology in adult bivalves has been demonstrated only for two major diseases: brown ring disease (BRD) in manila clams, $\underline{\text { Ruditapes philippinarum }}$ and $\underline{\mathrm{R}}$. decussatus (Paillard and Maes, 1990) and nocardiosis in the Pacific Oyster, Crassostrea gigas (Friedman et al., 1991; Friedman and Hedrick, 1991). BRD is a pathological condition

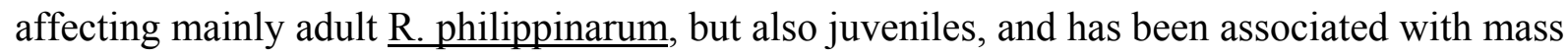
mortalities causing important economic losses in Europe (Paillard and Maes, 1989; Castro et al., 1992; Figueras et al., 1996). The etiological agent of BRD is a Vibrio named Vibrio P1 (Paillard and Maes, 1990; Paillard et al., 1994) or Vibrio tapetis (Borrego et al., 1996). The major sites of infection of $\underline{\mathrm{V} \text {. tapetis }}$ in clams are the periostracal lamina and the extrapallial fluids (Paillard and Maes, 1995a; Paillard and Maes, 1995b; Allam et al., 1996). The

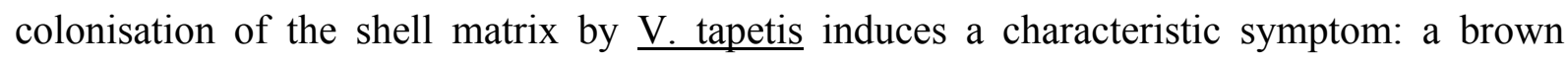
deposit of melanised shell matrix on the inner surface of the valves (Paillard and Maes, 1994;

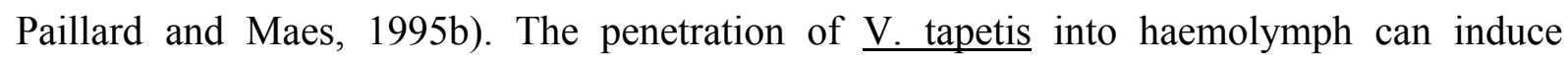
mortality before the clam exhibits BRD symptoms (Allam et al., 2002; Paillard, 2004b). Identification of $\underline{\mathrm{V} \text {. tapetis }}$ has been performed by using biochemical criteria (Borrego et al., 1996) and serological procedures (Paillard and Maes, 1995a; Paillard and Maes, 1995b; Allam et al., 1996; Allam et al., 2000; Castro et al., 1996; Nöel et al., 1996). Intraspecific characterisation of $\underline{\mathrm{V} \text {. tapetis }}$ has been done by pulse-field gel electrophoresis, ribotyping and plasmid profiles (Castro et al., 1997; Romalde et al., 2002; Le Chevalier et al., 2003). However, these methods are time consuming and ill-adapted to individual screening of clams and to detect asymptomatic, but infected, clams, which is the required condition to enhance a hatchery strategy. In recent years, several methods allowing bacterial identification from 
environmental samples have been developed on the basis of rRNA phylogenetic classification. These methods include in situ probing, dot blot hybridisation, sequencing of 16S rDNA clone libraries, single-strand conformation polymorphism (SSCP) analysis of a PCR-amplified variable region (Peters et al., 2000; Widjojoatmodjo et al., 1995) and denaturing gradient gel electrophoresis (DGGE) analysis (Gillan et al., 1998). Furthermore, methods have been developed for specific identification of bacteria. These methods include arbitrarily primed PCR (AP-PCR), randomly amplified polymorphic DNA (RAPD) and species-specific primed-PCR (SSP-PCR). In the majority of these examples, the targeted sequences are located outside the 16S or 23S rRNA genes (Hozbor et al., 1999; Lee et al., 1994; Pooler et al., 1996; Tilsala-Timisjarvi and Alatossava, 1998; Yamazaki and Nakamura, 1995). Variable regions of the $16 \mathrm{~S}$ and $23 \mathrm{~S}$ rRNA and tRNA genes have been used, among others, to specifically identify Coxialla burnetii (Ibrahim et al., 1997), Xanthomonas

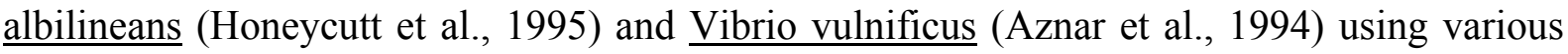
methods.

In this study we describe a specific $16 \mathrm{~S}$ rDNA probe and species-specific primers allowing a

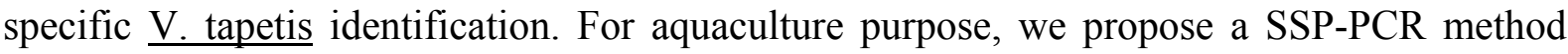
applicable for fast and sensitive $\underline{\mathrm{V}}$. tapetis detection in larvae and broodstock from hatcheries.

\section{Materials and methods}

Bacterial strains. The 60 strains used in this study are listed in Table 2. This list includes the

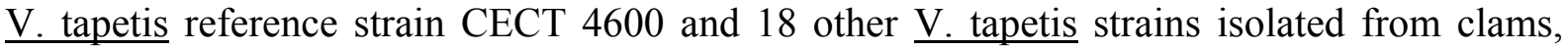
cockles and fishes. Twelve of the latter strains (IS-1; IS-5; IS-7; IS-8; IS-9; 2.3; 8.17; 9.7; 11.2; RD0705; RP 1703; RP 6301) have been identified as $\underline{\mathrm{V} \text {. tapetis }}$ on the basis of biochemical, serological and pathogenicity criteria (Maes, 1992; Maes and Paillard, 1992; 
Paillard et al., 1994; Novoa et al., 1998; Choquet, 2004) and genetic tests. Genetic tests included DNA/DNA Hybridisation for strains IS-,; IS-5, IS-7, 2.3, 8.17, 9.7, and 11.2; molecular typing using Ribotyping; Randomly Amplified Polymorphic DNA (RAPD) and Pulse-Field Gel Electrophoresis (PFGE) for these 12 strains (Borrego et al., 1996; Castro et al., 1997; Romalde et al., 2002 ). Four of the strains (P16b; UK6; P21; 29B) have been more recently identified as $\underline{\mathrm{V} \text {. tapetis }}$ on the basis of biochemical, serological and pathogenicity criteria (Allam et al., 1996; 2000; 2002; Paillard et al., 1997; Paillard et al., 2004b). DNA Gyrase B phylogenetic studies were performed on four strains, RD0705, IS-5, IS-7 and UK6 and P16 and have shown that these strains are grouped in the same clade as the reference $\underline{\mathrm{V}}$. tapetis CECT 46000 (Choquet, 2004). Two Vibrio sp., LP2 and HH6087, recently isolated

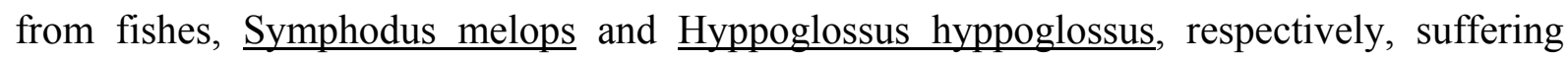
mortalities have been identified as $\underline{\mathrm{V} \text {. tapetis }}$ on the basis of serological test, phenotypic and genetic characterisation (16S rRNA gene for HH6087 and DNA-DNA hybridisation for LP2, and the Gyrase B gene for both strains) (Jensen et al., 2003; Reid et al., 2003; Choquet, 2004). Previous and recent studies have shown that the $\underline{\mathrm{V} \text {. tapetis }}$ isolates (strains IS1, IS5, IS7, IS8, IS9, P21, P16b, UK6, LP2 and HH6087) are able to induce the BRD symptoms (Maes, 1992; Allam et al., 2000; Choquet, 2004). The strain RD0202, a Vibrio $s p$ biochemically similar to $\underline{V}$. tapetis except for the lack of lactose fermentation, do not show positive agglutination with $\underline{\mathrm{V} \text {. tapetis }}$ anti-serum, but is able to reproduce BRD symptoms and mortalities in $\underline{\mathrm{R}}$. decussatus and R. philippinarum (Novoa et al., 1998; Choquet, 2004). The two strains, P9 and

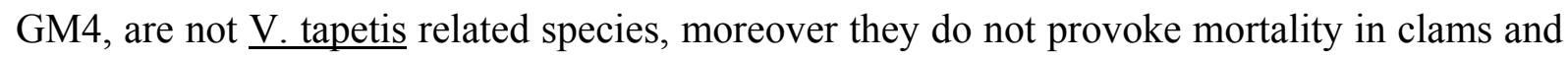
only GM4 can induce BRD symptoms in very low prevalence (15\%) compared to $\underline{\mathrm{V} \text {. tapetis }}$ strains (60 to 90\%) (Choquet, 2004).

For the present study, Vibrios and unrelated Gram positive and negative bacteria, and marine bacteria. $\underline{\text { V. tapetis }}$ (CECT 4600) were grown at $20^{\circ} \mathrm{C}$ on Trypticase soy agar (TSA, Difco) 
adjusted to $1.5 \% \mathrm{NaCl}$. Other marine bacteria were grown at $20^{\circ} \mathrm{C}$ in Marine Agar (Difco). The reference strains were grown under the conditions recommended by the ACTT.

\section{Clams}

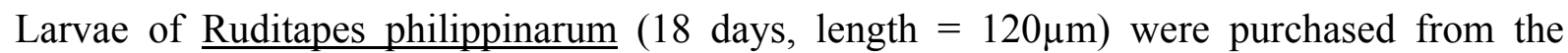
SATMAR hatchery (Gatteville, France). Adults $(30-40 \mathrm{~mm})$ were sampled from clam beds cultured by the SATMAR society in the Chausey Islands.

\section{Larval culture and challenge experiment}

Larvae were placed in a glass beaker ( $2 \mathrm{~L}$ of sterile sea water, SSW), at 5 larvae/ml (on

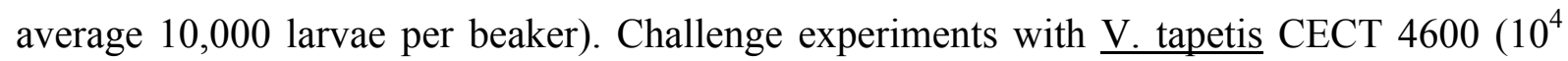
CFU ml ${ }^{-1}$ ) were performed 2 days after reception and over a period of 15 days using three different conditions (control larvae, challenged larvae, and no larvae but with $\underline{\mathrm{V} \text {. tapetis }}$ alone in seawater), all done in triplicate. $\underline{V}$. tapetis concentration was determined using a linear regression equation describing a relationship between Optical Density (OD at $492 \mathrm{~nm}$ ) and Total Heterotrophe Bacteria Counts (THBC) as first described in Paillard and Maes, 1990.

The larvae were fed with a mix of algae (Isochrisis galbana, Pavlova lutheri, and Chaetoceros pumilum). Larval culture temperatures were performed at 18 and $23^{\circ} \mathrm{C}$, in order to satisfy the host $\left(23^{\circ} \mathrm{C}\right.$ is generally used in the hatchery) and the pathogen ( $\underline{\mathrm{V} \text {. tapetis }}$ optimal growth temperature is $18^{\circ} \mathrm{C}$ ) (Paillard et al., 1997; Paillard et al., 2004b). Sea water and algal food were renewed 3 times a week. $\underline{V}$. tapetis detection was performed in larvae after 2 (T2) and 15 days (T15) of culture. For this, the larvae in each beaker were collected on a gridded filter (around 100 larvae were sampled), rinsed three times with SSW and then blended for 30s in $100 \mu 1$ of SSW using a Polytron ${ }^{\mathrm{TM}}$ blender. Larval homogenates and aliquots of $100 \mu \mathrm{l}$ sea 
water sampled from beakers containing no larvae were stored below $-20^{\circ} \mathrm{C}$ until used for DNA extraction.

\section{BRD diagnostic in broodstock adults}

The BRD symptom is characterized by a brown organic conchiolin deposit at the inner face of the valves. This conchiolin deposit can be partially or completely covered by shell layers as a function of the shell repair process (Paillard and Maes, 1994). The development of and recovery from $\mathrm{BRD}$ is assessed by scoring macroscopic symptoms according to the classification system established by Paillard and Maes (1994) and recently modified by (Paillard 2004a, b). In this portion of the study, three main groups of clams have been considered: the asymptomatic ones which present no BRD symptoms, the diseased ones, which present a conchiolin deposit partially covered by shell layers and the recovered clams, which have completely covered the conchiolin deposit by calcified shell layers (Table 3). In fact, the clams which developed the disease during the experiment, independently of the issue, correspond to group 2 and 3.

\section{Diagnosis of BRD and detection of $V$. tapetis by PCR in broodstock clams}

Three hundred and twenty adult clams were marked individually with a permanent marker pen and then maintained in an aquarium $(250 \mathrm{~L})$ at $14^{\circ} \mathrm{C}$ with a continuous renewal of seawater (cf. results Table 3). Once a day, they were fed with a mix of algae (Pavlova lutheri,

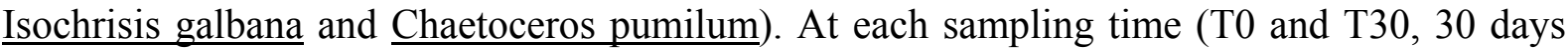
after the first sampling T0), the clams were placed in an anaesthetised solution $\left(5 \% \mathrm{MgCl}_{2}\right.$ in a 70/30 solution of distilled water/ seawater) until they opened their valves. After elimination of the pallial fluid, the extrapallial fluid was collected through a needle inserted in the sinusal, peripheral and central compartment as described by Paillard (2004b). Extrapallial fluids were 
frozen immediately at $-20^{\circ} \mathrm{C}$ to be used later for $\underline{\mathrm{V}}$. tapetis detection. BRD diagnosis was then individually performed on clams through binocular microscope observation as described above. The clams were then quickly returned to the aquarium to limit mortality due to the sampling.

At T0, fluids of 212 clams were individually sampled. Aliquots of $100 \mu 1$ from each clam was frozen for further analysis. The rest of fluids were distributed in 23 pools of 8 to 10 individuals (14 pools of 10 individuals and 9 pools of 8 ) and used for $\underline{V}$. tapetis detection by PCR. Microscopic examinations for signs of BRD were performed in all clams sampled for fluids, but only 112 individuals opened their valves sufficiently in the anaesthetised solution to be successfully diagnosed. At T30, BRD diagnosis was carried out on all survivors $(\mathrm{n}=$ 229) including at least 51 clams also sampled at T0. For these clams, $\underline{V}$. tapetis detection was performed using the individual samples collected at $\mathrm{T} 0$ and conserved at $-20^{\circ} \mathrm{C}$. Therefore, three categories of clams could be distinguished on the basis of $\underline{\mathrm{V} \text {. tapetis detection at } \mathrm{T} 0 \text { and }}$ BRD diagnosis at T0 and T30: Category I, no $\underline{\mathrm{V} \text {. tapetis }}$ at T0 and no BRD at T30; Category

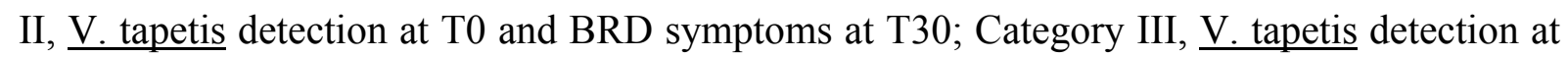
$\mathrm{T} 0$ and BRD recovery at T30. At T30, fluids from clams in categories II and III were grouped into two pools of 9-10 individuals each, which were used for $\underline{\mathrm{V} \text {. tapetis }}$ detection (Table 3$)$.. The 8 individuals in category I were grouped into a single pool. Another pool of individuals sampled only at T30 and showing no BRD symptoms $(\mathrm{n}=12)$ was also included. In total, $V$. tapetis detection was performed using the individual samples of 58 clams (Table 3).

\section{DNA extraction and 16S rDNA amplification}

DNA was extracted from $100 \mu$ of larval homogenate, sea water or the extrapallial fluid of adults according to the chelex method (Saulnier et al., 2000). For bacterial suspensions, total 
DNA was prepared from $1.5 \mathrm{ml}$ of saturated liquid culture according to Ausubel and collaborators (1990).

The 16S rDNA were PCR-amplified using the universal primers 616V and 1492R (Table 1) according to Kalmbach et al., (1997). PCR products were purified from agarose gels using the Ultrafree-DA kit (Millipore).

\section{Probe design and DOT BLOT hybridisation}

The Vt446 probe was deduced by the authors from the 16S rRNA gene sequence of the $\underline{\mathrm{V}}$. tapetis CECT 4600 strain (Accession $n^{\circ}$ : Y08430) by comparison with the sequences of 45 referenced Vibrio strains (sequence alignments not shown). Only the sequences of at least 1.4 $\mathrm{kb}$ were selected. The accession numbers of these strains are AB000278, AB000393, AB013297, AF007115, AF022409, AF064556, AF064557, AF064559, AF064637, AJ007045, AJ132227, M98446, U46579, U57919, X16895, X70640, X70641, X70643, $\mathrm{X} 74689, \mathrm{X} 74691, \mathrm{X} 74692, \mathrm{X} 74693, \mathrm{X} 74698, \mathrm{X} 74701, \mathrm{X} 74704$ to $\mathrm{X} 74708, \mathrm{X} 74710$ to X74717, X74719, X74721, X74723, X74725, X76333, X76335, X99761, X99762, and Z31657. The definition of this probe in the region of the $450^{\text {th }}$ nucleotide of the $16 \mathrm{~S}$ rRNA gene (Escherichia coli numbering) is in agreement with the target sites proposed for the molecular identification of the genus Vibrio (Dorsch et al., 1992).

Vt446 dot blot hybridisation were performed on $2 \mu \mathrm{l}$ of alkali-denatured PCR-amplified 16S rDNA, or $200 \mathrm{ng}$ of genomic DNA, onto a Hybond $\mathrm{N}+$ membrane according to the manufacturer's recommendations (Amersham). V. tapetis CECT 4600 DNA and Herring sperm DNA (Sigma) were used as positive and negative control, respectively. The Vt446 and the EUB338 oligonucleotidic probes (Table 1) were digoxigenine-labeled using a DIG Oligonucleotide 3'-End Labelling Kit (Boehringer). The EUB338 universal probe was designed by Aman et al. (1990). The DIG oligonucleotide labelling EUB338 probe was used 
to control the efficiency of the probe hybridisation and of the revelation process. Overnight hybridisation was performed at $54^{\circ} \mathrm{C}$ in Tris- $\mathrm{Cl}$ pH $8 \quad 50 \mathrm{mM}$ containing $3 \mathrm{M}$ tetramethylammonium chloride (Sigma), 2 mM EDTA, 5X Denhardt's and 0.1\% SDS. The membranes were washed twice in $2 \mathrm{X} \mathrm{SSC}, 0.1 \% \mathrm{SDS}$ at room temperature for $10 \mathrm{~min}$ and once for $30 \mathrm{~min}$ at $59^{\circ} \mathrm{C}$ in the hybridisation solution without Denhardt's. Positive signals were detected using the DIG Nucleic Acid Detection Kit (Boehringer).

\section{Agglutination test}

The agglutination assay was carried out as follows: $20 \mu 1$ of liquid culture bacteria were centrifuged at 13,000 g. The bacteria were resuspended in $5 \mu 1$ of phosphate buffered saline (PBS) and $5 \mu 1$ of an anti $\underline{\text { V. tapetis }}$ (CECT 4600) polyclonal antibody solution (Pasteur, France) were added. Anti V. cholerae (Pasteur, France) antibody was used as a negative control. The agglutination test was performed only for Vibrio species.

\section{PCR primers design}

The reverse primer, VtR, partially overlaps the Vt446 probe (Fig. 1) and this sequence is only present in the 16S rRNA gene of 8 bacteria (Accession n ${ }^{\circ}$ : AF007115, AF055811, AF055817, AF055833, D89929, M64339, U64006, and X74710). The alignment of these sequences with

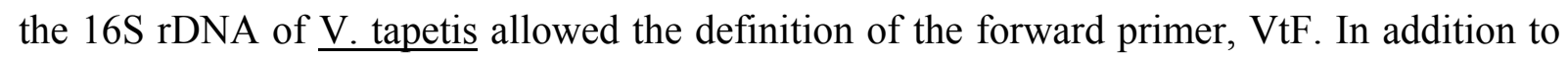
$\underline{\mathrm{V} \text {. tapetis, }}$, the sequence of this primer is $100 \%$ identical to sequences of only $\underline{\mathrm{V} \text {. pectenicida }}$ (Accession $n^{\circ}:$ Y13830) and $\underline{V}$. rumoence (Accession $n^{\circ}:$ AB013297). Moreover, at least 3 nucleotides at the terminal 3 'end of the $\mathrm{VtF}$ primer are absent from the VtF-complementary sequences of all the other $16 \mathrm{~S}$ rDNA. Therefore, we expected that this pair of primers would allow the amplification of a $416 \mathrm{bp}$ fragment specifically from the $\underline{\mathrm{V} \text {. tapetis }} 16 \mathrm{~S}$ rDNA. Sequences of the VtF and VtR primers are presented in Table 1. PCR reactions were 
performed in $50 \mu 1$ of $10 \mathrm{mM}$ Tris-Cl, $50 \mathrm{mM} \mathrm{KCl}$ containing $200 \mu \mathrm{M}$ of each dNTP, $1.5 \mathrm{mM}$ $\mathrm{MgCl}_{2}, 400 \mu \mathrm{M}$ of each primer, $0.2 \mathrm{U}$ of Taq DNA polymerase (Sigma), and 1 to $5 \mu \mathrm{l}$ of bacterial suspension or $200 \mathrm{ng}$ of genomic DNA. The thermal profile consisted of 35 cycles of $1 \mathrm{~min}$ at $94^{\circ} \mathrm{C}, 1 \mathrm{~min}$ at $63^{\circ} \mathrm{C}$, and $45 \mathrm{~s}$ at $72^{\circ} \mathrm{C}$ in a GeneAmp ${ }^{\mathrm{R}} \mathrm{PCR}$ system 9700 (Applied Biosystem). The positive control consisted of $\underline{\mathrm{V}}$. tapetis CECT 4600 DNA while the negative control was deionized water. To evaluate the sensitivity of the method, serial dilutions from 10 to $10^{6} \mathrm{CFU} / \mathrm{ml}$ of a culture of $\underline{\mathrm{V}}$. tapetis were performed in $\mathrm{SSW}$. The $\mathrm{CFU} / \mathrm{ml}$ was determined by plating onto marine agar. PCR-amplified DNA fragments were visualised under U.V. illumination after agarose gel electrophoresis $(1 \% \mathrm{~W} / \mathrm{V})$ and ethydium bromide staining. Ladders (100 pb DNA Ladder Promega (Figs. 3-5) and smart ladder Eurogentec (Fig. 6)) were used as a molecular weight marker.

\section{Probes and primers synthesis}

Probes and primers were synthesized by, and purchased from, PROLIGO (France) and EUROBIO (France).

\section{Results}

\section{Probe specificity}

The $\underline{\mathrm{V} \text {. tapetis }}$ probe, Vt446, was tested for specificity by comparison of dot blot hybridisation onto the PCR-amplified 16S rDNA from 50 different bacteria strains (Table 2). The Vt446 probe hybridised specifically to the PCR-amplified 16S rDNA, or genomic DNA (data not shown), of the $\underline{\mathrm{V} \text {. tapetis }}(\mathrm{Vt})$ reference strain and all other $\underline{\mathrm{V} \text {. tapetis }}$ strains (IS-1, IS-8, IS-5, IS-9, IS-7, P21, 29b, P16b, UK6) isolated from different clams (Fig 2; Table 2). All of these

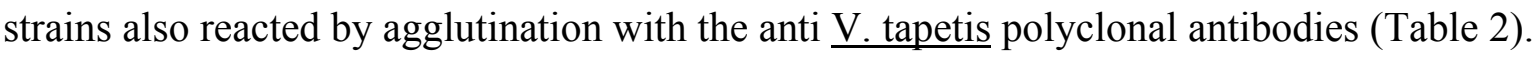




\section{PCR primers specificity and detection limit}

The $\mathrm{VtF}$ and $\mathrm{VtR}$ primers were designed to amplify a $416 \mathrm{bp}$ fragment from the $\underline{\mathrm{V} \text {. tapetis }}$ CECT4600 16S rDNA (Fig.1). The specificity of the PCR was tested with the purified DNA of the 60 different bacterial strains (Table 2). As suspected, a 416 bp PCR product was

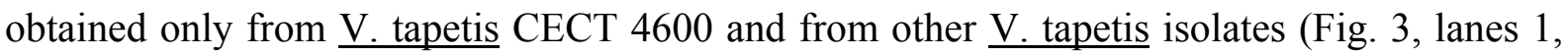
3-9). Whatever the method, Vt446 dot blot hybridisation, PCR amplification, or the agglutination test, all the $19 \mathrm{~V}$. tapetis strains (CECT 4600 and clam isolates) reacted positively (Table 2). The strains non pathogenic for clams, GM4 and P9, were negative in the PCR assay and presented only weak positive results with the agglutination test and dot blot

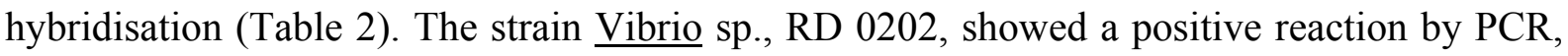
but a negative result with the agglutination test (Table 2).

To evaluate the sensitivity of this method, serial dilutions from 10 to $10^{6} \mathrm{CFU} / \mathrm{ml}$ of a $\underline{\mathrm{V}}$. $\underline{\text { tapetis }}$ liquid culture were performed and was verified by the plate count method. The detection limit was around $10^{2} \mathrm{CFU} \mathrm{ml} \mathrm{m}^{-1}$ (Fig. 4).

\section{Detection of $\underline{V}$. tapetis by PCR in clams}

\section{$\underline{\text { Larvae }}$}

Two days (T2) after reception from the hatchery, no $\underline{\mathrm{V} \text {. tapetis }}$ were detected by PCR in larvae. After 15 days of culture (T15) at $18^{\circ} \mathrm{C}$ (Fig. 5) and $23^{\circ} \mathrm{C}$ (data not shown), a $416 \mathrm{bp}$ PCR product was obtained in one of the six control beakers (at $23^{\circ} \mathrm{C}$ ). For all batches challenged with $\underline{\mathrm{V} \text {. tapetis }}$ at both temperatures, the presence of a single band of $416 \mathrm{bp}$ was obtained (lanes I1, I2, I3, $\underline{\mathrm{I}}, \underline{\mathrm{I}}, \underline{\mathrm{I}} 3$ ) (Fig. 5). In the seawater without larvae but containing $\underline{\mathrm{V}}$. tapetis CECT 4600 as control positive, as expected a 416 bp PCR product was obtained at T2 and also at T15. 


\section{$\underline{\text { Adult broodstock }}$}

At T0, the prevalence of BRD was very low $(0.89 \% ; 1 / 112)$ (Table 3$)$, but 7 out of $23(30.4 \%)$ batches generated a band of appropriate size when examined by PCR. At T30, the proportion of total clams that had developed BRD (Table 3) reached $51 \%(n=229)$, but $27 \%$ of them had recovered, as indicated by shell deposition over the organic deposit. For the clams which were diagnosed at both T0 and T30 $(n=51), \underline{V}$. tapetis presence was determined in each clam at T0 (Fig. 6). At T0, a positive PCR reaction was observed in some asymptomatic clams, which had developed BRD by T30 (Fig. 6, lanes 4-6, 10, 11) or recovered from BRD at T30 (lanes 7-9). In the recovered clams, $\underline{\mathrm{V} \text {. tapetis }}$ was still present, but at concentrations near the detection limit. Negative reactions at $\mathrm{T} 0$ were observed in clams that were asymptomatic at both T0 and T30 (Fig. 6, lanes 12, 13). At T30, V. tapetis PCR detection was performed on clams in categories I, II, and III (see in Material and Methods). Positive reactions were found only in clams from categories II and III. In the clams from category III (recovered clams), $\underline{\mathrm{V}}$. $\underline{\text { tapetis }}$ was nevertheless present but at concentrations near the detection limit. In clams from

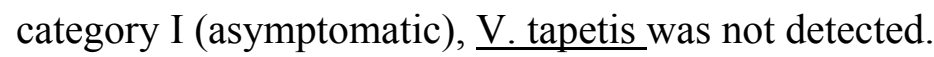

During the experiment, cumulative mortality reached $28 \%$ at T30 (Table 3). The dead clams belonged to all groups and the mortality could have been due to the stress associated with anaesthesia, fluid sampling, BRD examination as well as BRD development during the experiment.

\section{Discussion}

Identification of pathogenic bacteria isolated from diseased organisms is a very important challenge for pathologists. Phenotypic characterisation of bacteria (serotyping, physiology, biochemical properties, and metabolism) shows low reproducibility and instability depending on the culture conditions. Moreover, characterisation systems for marine bacteria are not very 
reliable and are time consuming. Molecular diagnostics, based on specific DNA fragment detection, compared to phenotypic characterisation, constitutes a reliable and rapid identification for numerous isolates. Many molecular identification methods, such as species specific probe hybridisation, sequencing of $16 \mathrm{~S}$ rDNA, SSCP and DGGE have been developed to identify pathogenic bacteria, especially those inducing infections in humans (Yamamoto, 2002; Peters et al., 2000). However, to date, few authors have reported molecular identification of the bacteria involved in diseases of marine bivalves. The present results have demonstrated that Dot blot hybridisation method using the Vt446 probe allowed the

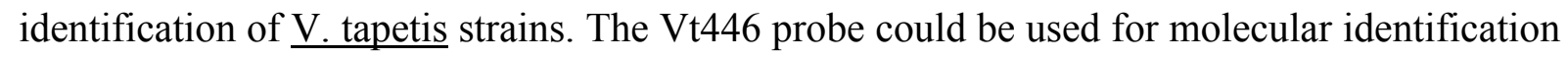
of bacteria from environmental samples (seawater, marine mud) by bacterial colony hybridisation of or in situ probing. Nevertheless, this method is time consuming (2-3 days), requires several steps and moreover some weak false positive reactions were suspected for GM4 and P9 strains. Therefore, we have developed a one step procedure on the basis of the PCR assay for rapid detection (one day) in clam aquaculture.

The specificity of PCR has been demonstrated to detect only $\mathrm{V}$. tapetis reference strain, CECT 4600, and the nineteen other $\underline{\mathrm{V} \text {. tapetis }}$ isolates. Moreover, for all the $19 \underline{\mathrm{V} \text {. tapetis }}$ strains, the results of PCR and the agglutination tests systematically corroborated each other. Identification of $\underline{\mathrm{V} \text {. tapetis }}$ using PCR seems to be more efficient than hybridisation or agglutination. This was illustrated by the strains P9 and GM4, both isolated from a clam, which were weakly positive for agglutination and hybridisation, and negative for PCR, suggesting a false positive hybridisation. Recent studies have demonstrated that both GM4

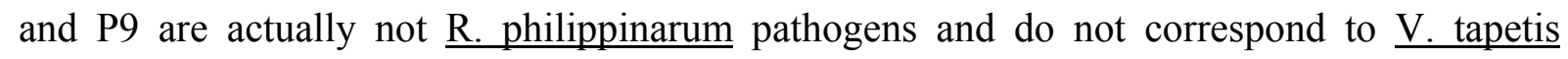
species (Choquet, 2004).

The species-specific primed-PCR (SSP-PCR) method, developed in this study, could be also

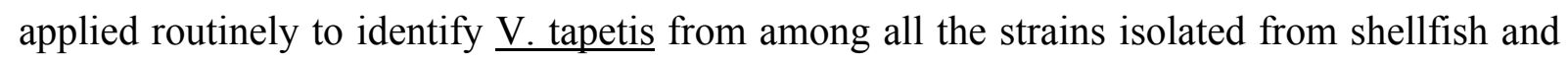


fishes suffering mortality in the field or hatchery. The SSP-PCR identification could be confirmed in a second step, at a physiological level. Their pathogenicity could be evaluated in vivo by BRD reproduction (Paillard and Maes, 1990) and by clam mortality tests (Allam et al., 2002) and in vitro by cytotoxicity assays (Choquet et al., 2004). These biological

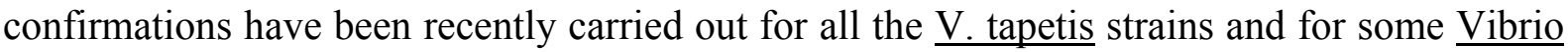
sp. which have shown positive results by SSP-PCR (Paillard, 2004a; Choquet, 2004). This is the case for the Vibrio sp, RD0202, which showed a positive reaction by SSP-PCR in the present study and which showed high pathogenicity against $\underline{\text { R. philippinarum after }}$ experimental challenge and in in vitro tests (Novoa et al., 1998; Choquet, 2004). DNA-DNA hybridisation and MLST (MultiLocus Sequence Technique) are in progress to confirm the relationship of RD0202 to $\underline{\mathrm{V} \text {. tapetis. }}$

Shellfish concentrate microorganisms in their tissues and fluids from surrounding waters during filtration and feeding processes and are recognised as reservoirs for numerous human pathogens. Outbreaks of shellfish-associated infection have increased considerably since the early 1970's (Potasman et al., 2002). Therefore, numerous applications of PCR-derived methods have been developed to detect human bacterial pathogens, such as Salmonella, Aeromonas hydrophila, E. coli and vibrios, in shellfish (Toze, 1999; Hervio-Heath et al., 2002). Molecular methods have been recently developed to identify bacterial pathogens for marine fishes and crustaceans, such as Yersinia ruckeri, $\underline{\text { A. salmonicida, Renibacterium }}$

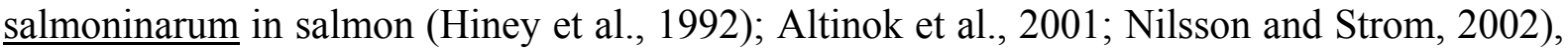

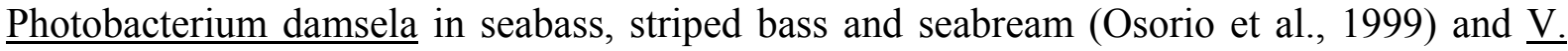
penaeicida in shrimp (Saulnier et al., 2000). Bacterial diseases have been often reported in bivalve larvae, but few have been described in adults (Paillard et al., 2004b). For instance, few molecular assays have been developed to detect bivalve bacterial pathogens. $\underline{\mathrm{V} \text {. tapetis }}$ 
detection is very important for BRD diagnosis because the clinical signs cannot be observed in larvae and juveniles (under $2 \mathrm{~mm}$ ), during the incubation period of 5 to 10 days before symptoms are observed in juveniles and adults, or in cases when the pathogen enters directly into tissues inducing death without provoking symptoms. The SSP-PCR method described in this study was developed primarily to detect this pathogen in larvae and adult broodstock in the hatchery. The utility of method for following infection and disease progression using haemolymph or extrapallial fluid sampling of individual adult clams was subsequently demonstrated.

For the first time, $\underline{\mathrm{V} \text {. tapetis }}$ was detected in larvae by the SSP-PCR assay. Until now, $\underline{\mathrm{V}}$. tapetis had never been isolated or detected in clams smaller than $2 \mathrm{~mm}$ in length when using ELISA methods. This could be due to the lower sensitivity of this latter method, since $\underline{\mathrm{V}}$. tapetis detection limit using ELISA technique is about $5 \cdot 10^{4} \mathrm{CFU} \mathrm{ml}^{-1}$ in SSW or in fluids (Allam et al., 2002; Paillard, 2004a; Noël et al, 1996). Larvae are generally very sensitive to pathogenic vibrios and cannot harbour concentrations higher than $10^{5} \mathrm{CFU} \mathrm{ml}{ }^{-1}$ without suffering mortalities (Tubiash, 1973). In the present study, the larval challenge experiment with $\underline{\mathrm{V}}$. tapetis was performed at $10^{4} \mathrm{CFU} \mathrm{ml^{-1 }}$ without causing mortalities. In previous experiments (Paillard et al., unpublished data) $\underline{\text { V. tapetis }}$ at this concentration did not induce severe mortalities in clam larvae; however, a concentration of $10^{6} \mathrm{CFU} \mathrm{ml^{-1 }}$ was able to induce mortalities of $70 \%$ and $50 \%$ in D larvae and in metamorphic larvae after nine days of culture, respectively. In the present study, a positive reaction by PCR was obtained in one of the three control beakers after 15 days of larval culture at $23^{\circ} \mathrm{C}$; this suggest that some batches of larvae were previously contaminated at low level in the hatchery. The SSP-PCR detection assay seems to be effective for detecting lower concentrations than $510^{4} \mathrm{CFU} \mathrm{ml}^{-1}$ of $\underline{\mathrm{V}}$. tapetis (detection limit for ELISA) in larvae and could be applied routinely in hatcheries to prevent larval and juvenile mortality episodes and to limit dissemination of BRD. 
Another study in which BRD progression was followed in individual clams used ELISA to detect $\underline{\mathrm{V} \text {. tapetis }}$ also showed that, during recovery, $\underline{\mathrm{V} \text {. tapetis }}$ burdens decreased and were at very low levels, approaching the detection limit for ELISA, when clam had completely recovered (Paillard, 2004a; Paillard and Ford, unpublished data). Nevertheless, ELISA detection did not permit distinguishing infected, but asymptomatic, clams from uninfected ones, because $\underline{\mathrm{V} \text {. tapetis }}$ burdens in both cases were generally too close to the ELISA detection limit (Paillard, 2004a). In the present study, the SSP-PCR method allows the detection of $\underline{\mathrm{V} \text {. tapetis }}$ in infected, but asymptomatic clams: asymptomatic clams that were

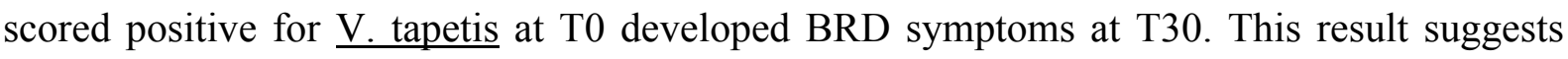
that SSP-PCR reaction could be used to detect early infections. The fact that some clams remained uninfected during the whole experiment (no $\underline{\mathrm{V} \text {. tapetis }}$ detected and no BRD at T30), and that the pathogen can also be eliminated with the recovery process, even if they are

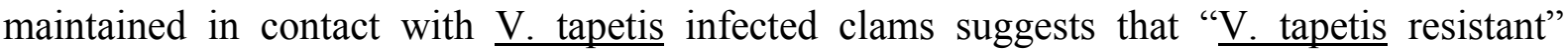
broodstock could be identified using the SSP-PCR method. In addition, the SSP-PCR method

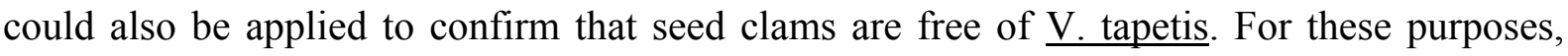
development of a quantitative PCR method is in progress using these specific primers. In conclusion, the SSP-PR method is sensitive, specific and rapid for identifying $\underline{\text { V. tapetis }}$ among isolates from diseased and moribund clams. The two SSP-PCR primers are useful for

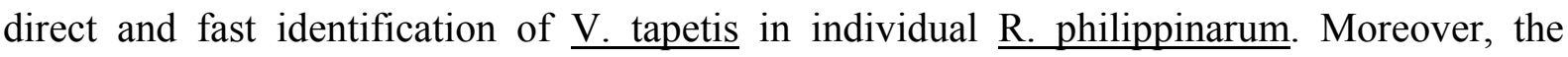
rapidity and specificity of SSP-PCR suggest that this latter method is well adapted to detect

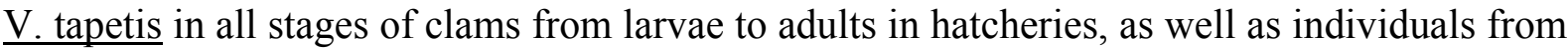

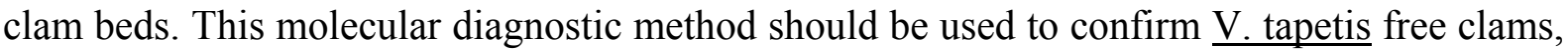
in order to enhance venerid culture along the north European Atlantic coast. Nevertheless, the possibility that a wild bacteria type, unreferenced in the databases, will positively hybridise with the Vt446 probe and/or result in a positive SSP-PCR amplification cannot be excluded. 
Further improvements of molecular diagnostic tests are currently in progress in order to develop real-time quantification methods. The methods developed in the present study for clams will be applied, after modification, for the screening of $\underline{\mathrm{V} \text {. tapetis in bivalve species }}$ other than clams, including fishes. These methods will be of great value for monitoring $\underline{\mathrm{V}}$. $\underline{\text { tapetis }}$ in the marine environment in order to establish its host species among invertebrates and vertebrates and its geographical distribution around the world.

\section{Acknowledgements}

This study has been carried out with financial support from the Brittany Region and the National Coastal Ecosystems Programme ("Programme National Ecosysteme Côtier, PNEC"). We greatly thank Oivind Bergh for kindly providing the strain LP2 and Harry Birbeck for the strain HH6087as well as Clément Bovo, Lénaïck Gourant, Alain Marhic, Christel Marty and Michelle Le Tonqueze for technical and scientific assistance. We also greatly thank Satmar (Gatteville, Chausey and Marennes Oléron, France ) in particular Jean Francois Auvray, Jean Francois Thoulorge and Jean Yves Leborgne for providing adult and larval clams.

We thank greatly David P. Gillikin and S. E. Ford for correcting this manuscript.

\section{References}


Allam, B., Paillard, C., Maes, P., 1996. Localization of the pathogen Vibrio P1 in clams affected by Brown Ring Disease. Dis. Aquat. Org. 27, 149-155.

Allam, B., Paillard, C., Ford, S.E., 2002. Pathogenicity of Vibrio tapetis, the etiological agent of Brown Ring Disease (BRD) in clams. Dis. Aquat. Org. 48, 221-231.

Allam, B., Paillard, C., Howard, A., Le Pennec, M., 2000. Isolation of the pathogen Vibrio $\underline{\text { tapetis }}$ and defense parameters in brown ring diseased Manila clams Ruditapes philippinarum cultivated in England. Dis. Aquat. Org. 41, 106-113.

Amann, R.I., Krumholz L., Stahl, D.A., 1990. Fluorescent oligonucleotide probing of whole cell for determinative, phylogenetic and environmental studies in microbiology. J. Bacteriol. 172 : 762-770.

Altinok, I., Grizzle, J.M., Liu, Z., 2001. Detection of Yersinia ruckeri in rainbow trout blood by use of the polymerase chain reaction. Dis. Aquat. Org. 44, 29-34.

Ausubel, F.M., Brent, R., Kingston, R.E., Moore, D.D., Seidman, J.G., Smith , J.A., 1990. Current Protocols in Molecular Biology. Willey and Sons, New York, NY.

Aznar, R., Ludwig, W., Amann, R.I., Schleifer, K.H., 1994. Sequence determination of rRNA genes of pathogenic $\underline{\text { Vibrio }}$ species and whole-cell identification of $\underline{\text { Vibrio vulnificus }}$ with rRNA-targeted oligonucleotide probes. Int. J. Syst. Bacteriol. 44, 480-484.

Borrego, J.J., Castro, D., Luque, A., Paillard, C., Maes, P., Garcia, M.T., Ventosa, A., 1996. Vibrio tapetis sp.nov. the causative agent of the Brown ring disease affecting cultured clams.Int. J. Syst. Bact. 46, 480-484.

Castro, D., Santamaria, J.A., Luque, A., Martinez-Manzanares, E., Borrego, J.J., 1996. Antigenic characterization of the etiological agent of the brown ring disease affecting manila clams. Syst. Appl. Microbiol. 19, 231-239. 
Castro, D., Romalde, J.L., Vila, J., Magarinos, B., Luque, A., Borrego, J.J., 1997. Intraspecific characterization of $\underline{\text { Vibrio tapetis }}$ strains by use of pulse-field gel electrophoresis, ribotyping, and plasmid profiling. Appl. Env. Microbiol. 63, 14491452.

Castro, D., Martinez-Manzanares, E., Luque, A., Fouz, B., Moriñigo, M.A., Borrego, J.J., Toranzo, A.E., 1992. Characterization of strains related to brown ring disease outbreaks in southwestern Spain. Dis. Aquat. Org. 14, 229-236.

Choquet, G., Soudant, P., Lambert, C., Nicolas, J.L., Paillard, C., 2003. Reduction of adhesion properties on Ruditapes philippinarum hemocytes exposed to Vibrio tapetis. Dis. Aquat. Org. 57, 109-116.

Choquet, 2004. Pathogénie de Vibrio tapetis, bactérie responsable de la maladie de l'anneau brun chez la palourde: Approche cellulaire et moléculaire. Thèse de doctorat. Université de Brest. 150p.

Dorsch, M., Lane, D., Stackebrandt, E., 1992. Towards a phylogeny of the genus Vibrio basedon 16S rRNA sequences. Int. J. Syst. Bacteriol. 42, 58-63.

Figueras, A.J., Robledo, A.F., Novoa, B., 1996. Brown ring disease and parasites in clams

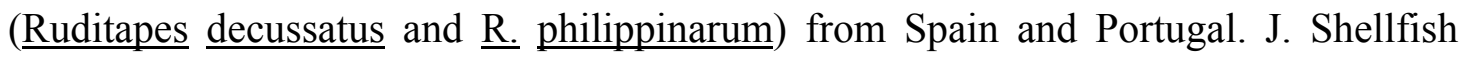
Res. 15, 363-368.

Friedman, C.S., Hedrick, R.P., 1991. Pacific oyster nocardiosis: Isolation of the bacterium and induction of laboratory infections. J. Invertebr. Pathol. 57, 109-120.

Friedman, C.S., Beattie, J.H., Elston, R.A., Hedrick, R.P., 1991. Investigation of the relationship between the presence of a Gram-positive bacterial infection and summer mortality of the Pacific oyster, Crassostrea gigas Thunberg. Aquaculture 94, 1-15. 
Gillan, D.C., Speksnijder, A.G., Zwart, G., De Ridder, C., 1998. Genetic diversity of the biofilm covering Montacuta ferruginosa (Mollusca, bivalvia) as evaluated by denaturing gradient gel electrophoresis analysis and cloning of PCR-amplified gene fragments coding for 16S rRNA. Appl. Env. Microbiol. 64, 3464-3472.

Hervio-Heath D., Colwell R.R., Derrien A., Robert-Pillot A., Fournier J.M., Pommepuy M., 2002. Occurrence of pathogenic vibrios in coastal areas of France J. Appl. Microbiol., vol. 92 , no. $6,1123-1135$.

Hiney M., Dawson M.T., Heery DM, Smith PR, Gannon F and Powell R 1992. DNA probe for Aeromonas salmonicida. Appl. Environ. Microbiol., 58 (3). 1039-1042,

Honeycutt, R.J., Sobral, B.W., McClelland, M., 1995. tRNA intergenic spacers reveal polymorphisms diagnostic for Xanthomonas albilineans. Microbiology. 141, 32293239.

Hozbor, D., Fouque, F., Guiso, N., 1999. Detection of Bordetella bronchiseptica by the polymerase chain reaction. Res Microbiol. 150, 333-341.

Ibrahim, A., Norlander, L., Macellaro, A., Sjostedt, A., 1997. Specific detection of Coxiella burnetii through partial amplification of 23S rDNA. Eur. J. Epidemiol. 13, 329-334.

Jensen, S., Samuelsen, O.B., Andersen, K., Torkildsen, L., Lambert, C., Choquet, G., Paillard, C., Bergh, O., 2003. Characterization of strains of Vibrio splendidus and Vibrio tapetis isolated from corkwing wrasse Symphodus melops suffering vibriosis. Dis. Aquat. Org. 53, 25-31.

Kalmbach, S., Manz, W., Szewzyk, U., 1997. Isolation of new bacterial species from drinking water biofilms and proof of their in situ dominance with highly specific $16 \mathrm{~S}$ rRNA probes. Appl. Env. Microbiol. 63, 4164-4170. 
Le Chevalier, P., Le Boulay, C., Paillard, C., 2003. Characterization by restriction fragment

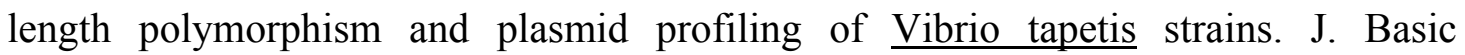
Microbiol. 43. 414-422.

Lee, T.Y., Lee, T.J., Kim, S., 1994. Differentiation of Mycobacterium tuberculosis strains by arbitrarily primed polymerase chain reaction-based DNA fingerprinting. Yonsei Med. J. 35, 286-294.

Maes, P., 1992. Pathologie bactérienne chez deux invertébrés marins; la maladie des lésions vertes des échinides réguliers et la maladie de l'anneau brun de la palourde, $\underline{\text { Ruditapes }}$ philippinarum. Thèse de Doctorat. Brest. 204 p.

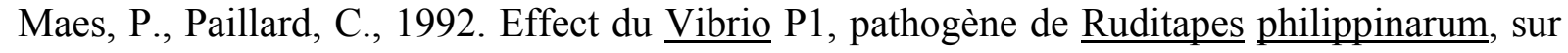
d'autres espèces de bivalves. Les Molluscques Marins, Biologies et Aquaculture. IFREMER, Actes de Colloques 14, 141-148.

McGladdery, S.E., 1999. Shellfish diseases (viral, bacterial and fungal). Woo, P. T. K., and Bruno, D. W., (Eds). Fish diseases and disorders. pp 738-842.

Nilsson, W.B., Strom, M.S., 2002. Detection and identification of bacterial pathogens of fish in kidney tissue using terminal restriction fragment length polymorphism (T-RFLP) analysis of 16SRNA genes. Dis. Aquat. Org. 48, 175-185.

Nöel, D., Nicolas, J.-L., Boulo, V., Mialhe, E., Roch, P., 1996. Development of a colony-blot ELISA assay using monoclonal antibodies to identify Vibrio $\mathrm{P} 1$ responsible for "brown ring disease" in the clam Tapes philippinarum. Aquaculture 146, 171-178.

Novoa, B., Luque, A., Castro, D., Borrego, J. J., Figueras, A., 1998. Characterization and infectivity of four bacterial strains isolated from Brown Ring Disease-affected clams. J. Invertebr. Pathol. 71, 34-41. 
Osorio, C.R., Collins, M.D., Toranzo, A.E., Barja, J.L., Romalde, J.L., 1999. 16S rRNA gene sequence analysis of Photobacterium damselae and nested PCR method for detection of the causative agent of fish pasteurellosis. Appl. Environ. Microbiol. 65, 2942-2946.

Paillard C., 2004a. Rôle de l'environnement dans les interactions hôtes-pathogènes ; développement d'un modèle de vibriose chez les bivalves. Habilitation à Diriger des Recherches (HDR). State Doctorat. Université de Bretagne Occidentale. 177 pp.

Paillard, C., 2004b. Review of brown ring disease, a vibriosis affecting clams. Aquat. Living Ress. ("Special issue on bivalve diseases") Vol 17, 4, 467-475.

Paillard C., Leroux F. and Borrego J.J. 2004a. Bacterial Disease in marine Bivalves : Review of recent studies. Trends and evolution. Aquat. Living Ress. ("Special issue on bivalve diseases", 17. 477-498.

Paillard C., Allam B. and Oubella R. 2004b, Temperature effects on Brown Ring Disease susceptibility and defense-related activities in clams Ruditapes philippinarum. Dis. Aquat. Org. vol 59, 249-262.

Paillard, C., Maes, P., 1989. Origine pathogène de l'"anneau brun" chez Tapes philippinarum (Mollusque, bivalve). C. R. Acad. Sci. Paris, Série III 309, 235-241.

Paillard, C., Maes, P., 1990. Étiologie de la maladie de l'anneau brun chez Tapes philippinarum: pathogenicité d'un Vibrio sp. C. R. Acad. Sci. Paris, Série III 310, $15-20$

Paillard, C., Maes, P., 1994. The brown ring disease symptom in the manila clam, $\underline{\text { Ruditapes }}$ philippinarum: establishment of a classification system. Dis. Aquat. Org. 19, 137146. 
Paillard, C., Maes, P., 1995a. The Brown Ring Disease in the Manila clam, $\underline{\text { Ruditapes }}$ philippinarum. I. Ultrastructural alterations of the periostracal lamina. J. Invertebr. Pathol. 65, 91-100.

Paillard, C., Maes, P., 1995b. The Brown Ring Disease in the Manila clam, Ruditapes philippinarum. II. Microscopic study of the brown ring syndrome. J. Invertebr. Pathol. $65,101-110$.

Paillard, C., Maes, P., Oubella, R., 1994. Brown Ring Disease in Clams. Annual Review of Fish Diseases. 4, 219-240.

Paillard, C., Maes, P., Mazurié, J., Claude, S., Marhic, A., Le Pennec, M., 1997. Epidemiological survey of the brown ring disease in clams of the Atlantic coast: role of temperature in variation of prevalence, Eighth Symposium of the International Society for Veterinary Epidemiology and Economics. (ISVEE'97), July 8-11. Paris, France.

Peters, S., Koschinsky, S., Schwieger, F., Tebbe, C.C., 2000. Succession of microbial communities during hot composting as detected by PCR-single-strand-conformation polymorphism-based genetic profiles of small-subunit rRNA genes. Appl. Env. Microbiol. 66, 930-936.

Pooler, M.R., Ritchie, D.F., Hartung, J.S., 1996. Genetic relationships among strains of

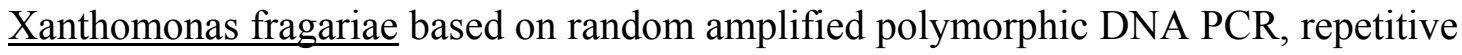
extragenic palindromic PCR, and enterobacterial repetitive intergenic consensus PCR data and generation of multiplexed PCR primers useful for the identification of this phytopathogen. Appl. Env. Microbiol. 62, 3121-3127.

Potasman, I., Paz, A., Odeh, M., 2002. Infection outbeaks associated with bivalve shellfish consumption : a worldwide perspective. Clin. Infect. Dis. 35, 921-928. 
Reid, H.I., Duncan, H.I., Laidler, A., Hunter, D., Birkbeck, T.H., 2003. Isolation of Vibrio

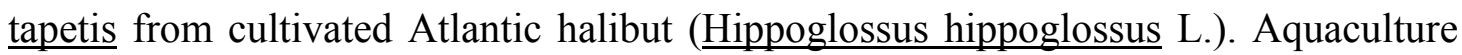
$221,65-74$.

Romalde, J.L., Castro, D., Magarinos, B., Lopez-Cortes, L., Borrego, J.J., 2002. Comparison of ribotyping, randomly amplified polymorphic DNA, and pulsed-field gel electrophoresis for molecular typing of Vibrio tapetis. Syst. Appl. Microbiol. 25, 544550.

Saulnier, D., Avarre, J.C., Le Moullac, G., Ansquer, D., Levy, P., Vonau, V., 2000. Rapid and sensitive PCR detection of Vibrio penaeicida, the putative etiological agent of syndrome 93 in New Caledonia. Dis. Aquat. Org. 40, 109-115.

Sindermann, C.J., 1990. Diseases of Marine Shellfish. Academic Press Publishers, San Diego, $516 \mathrm{pp}$.

Tilsala-Timisjarvi, A., Alatossava, T., 1998. Strain-specific identification of probiotic Lactobacillus rhamnosus with randomly amplified polymorphic DNA-derived PCR primers. Appl. Env. Microbiol. 64, 4816-4819.

Toze Simon. 1999. PRC detection of microbial pathogens in water and wastewater. Review. Wat. Res. Vol 33, 17, 3545-3556.

Tubiash, H. S., 1975. Bacterial pathogens associated with cultured bivalve mollusk larvae. Culture of Marine Invertebrate Animals. Plenum, New York, pp. 61-71.

Widjojoatmodjo, M.N., Fluit, A.C., Verhoef, J., 1995. Molecular identification of bacteria by fluorescence-based PCR-single-strand conformation polymorphism analysis of the 16S rRNA gene. J. Clin. Microbiol. 33, 2601-2606.

Yamamoto, Y., 2002. PCR in diagnosis of infection: detection of bacteria in cerbrospinal fluids. Clin. Diagn. Lab. Immunol. 9, 508-514. 
Yamazaki, T., Nakamura, R.M., 1995. Identification of Mycobacterium intracellulare by a polymerase chain reaction using species-specific primers. Tuber. Lung Dis. 76, 330335. 


\section{Figure captions}

Figure 1. Localisation of the Vibrio tapetis $16 \mathrm{~S}$ rRNA gene oligonucleotidic probe Vt446 (bold letters) and species-specific primers VtF and VtR (underlined). Positions are referenced to the 16S rRNA genes of $\underline{E}$. coli (accession V00348) and V. tapetis (accession Y08430), respectively. $*$ : identical nucleotides.

Figure 2. Dot Blot hybridisation with the Vt446 (A) or the EUB338 (B) probe on PCRamplified 16S rDNA from strains of $\underline{\mathrm{V} \text {. tapetis }}(\mathrm{Vt})$, other $\underline{\text { Vibrio }}$ species (V, Vf, Val, Vp, Vs, Van) their strain names are bracketed as defined in Table 2. Hs : negative control (herring sperm DNA), C : positive control of the revelation procedure.

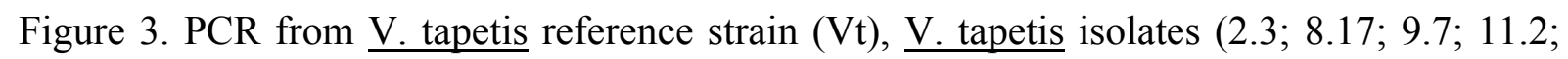
RD 0202; RP 1703) and two Vibrio sp. (GM4 and P9). $\varnothing$ : negative control.

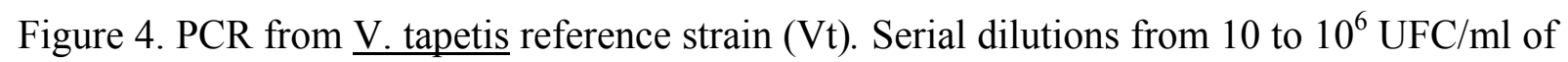
liquid culture. $\varnothing$ : negative control.

Figure 5. PCR detection of $\underline{\mathrm{V} \text {. tapetis }}$ in larvae incubated at $18^{\circ} \mathrm{C}$, after two days (not underlined) and after 15 days (underlined). Two different conditions in replicates: C, Control unchallenged larvae; I, $\underline{\mathrm{V} \text {. tapetis }}$ challenged larvae. Vt, $\underline{\mathrm{V} \text {. tapetis }}$ in sea water. $\varnothing$ : negative control.

Figure 6. SSP-PCR detection of $\underline{\mathrm{V} \text {. tapetis }}$ in extrapallial fluid derived from individual clam

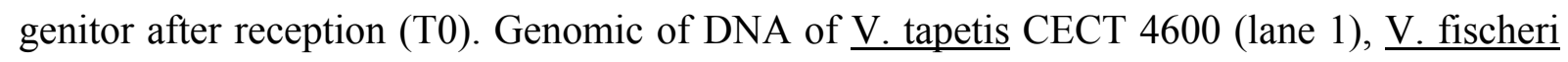
and $\underline{\mathrm{V} . \text { splendidus }}$ (lanes 2 and 3 ) were used as positive and negative controls. Asymptomatic 
clams at T0 which have developed BRD at T30 (lanes 4-6, 10 and 11), those which have recovered from BRD at T30 (lanes 7-9) and which were healthy at T30 (lanes 12 and 13). $\varnothing$ : negative control.

Table 1. Nucleotidic sequences of the probes and primers used.

\begin{tabular}{|c|c|c|c|c|}
\hline Probe & Specificity & Sequence $\left(5^{\prime}-3^{\prime}\right)$ & Target site & Reference \\
\hline EUB338 & Bacteria & GCTGCCTCCCGTAGGAGT & $16 \mathrm{~S}(337-354)^{\mathrm{a}}$ & Aman et al., 1990 \\
\hline $616 \mathrm{~V}$ & Universal & AGAGTTTGATYMTGGCTCAG & $16 S(8-27)^{a}$ & Kalmbach et al., 1997 \\
\hline $1492 \mathrm{R}$ & Universal & CGGYTACCTTGTTACGAC & $16 \mathrm{~S}(1493-1510)^{\mathrm{a}}$ & Kalmbach et al., 1997 \\
\hline Vt446 & $V$. tapetis & AGCGTGCATCCTTGACGT & $16 \mathrm{~S}(446-463)^{\mathrm{b}}$ & this study \\
\hline $\mathrm{VtF}$ & $V$. tapetis & CGAGCGGAAACGAGAAGTAG & $16 \mathrm{~S}(55-75)^{\mathrm{b}}$ & this study \\
\hline VtR & $V$. tapetis & GGATGCACGCTATTAACGTACA & $16 \mathrm{~S}(450-472)^{\mathrm{b}}$ & this study \\
\hline
\end{tabular}


Table 2. Bacterial strains used to confirm the $\mathrm{V}$. tapetis specificity of the Vt446 probe and the PCR reaction. -, negative reaction. + , weak positive reaction, +++ , strong positive reaction. nd, not determined. ATCC, American Type Culture Collection; CECT, Collecciōn Espagnola de Cultivos Tipos ; CIP, Collection de l'Institut Pasteur.

\begin{tabular}{|c|c|c|c|c|c|c|}
\hline Bacteria & $\begin{array}{c}\text { Strain } \\
\text { designation }\end{array}$ & Source & Origin & $\begin{array}{c}\text { Hybridisation } \\
\text { Vt446 }\end{array}$ & PCR & Agglutination \\
\hline Vibrio tapetis & $\mathrm{Vt}$ & Collection & CECT 4600 & +++ & +++ & +++ \\
\hline Vibrio fischeri & $\mathrm{Vf}$ & Collection & ACTT 7744 & - & - & - \\
\hline Vibrio anguillarum & Van & Collection & ACTT 19105 & - & - & - \\
\hline Vibrio alginolyticus & Val & Collection & ACTT 17749 & - & - & - \\
\hline Vibrio splendidus & Vs. & Collection & ACTT 25914 & - & - & - \\
\hline Vibrio pectenicida & $\mathrm{Vp}$ & Collection & CIP 105190 & - & - & - \\
\hline Vibrio natriegens & $\mathrm{Vn}$ & Collection & ACTT 14048 & - & - & - \\
\hline Vibrio haloplanktis & $\mathrm{Vh}$ & Collection & ACTT 14393 & - & - & - \\
\hline Vibrio costicola & Vco & Collection & ACTT 33508 & - & - & - \\
\hline Vibrio damsela & $\mathrm{Vd}$ & Collection & ACTT 33536 & - & - & - \\
\hline Vibrio carchariae & Vca & Collection & ACTT 35084 & - & - & - \\
\hline Vibrio mytili & $\mathrm{Vm}$ & Collection & CECT 632 & - & - & - \\
\hline Vibrio sp. 56 & T9a-3 $\beta$ & R. philippinarum & Sligo, Ireland & - & - & - \\
\hline Vibrio sp. UK & UKC & R. philippinarum & United kingdom & - & - & - \\
\hline Vibrio sp. IRL & BSI & R. philippinarum & Sligo, Ireland & - & - & - \\
\hline Vibrio sp. & GM3 & R. philippinarum & Morbihan Gulf, France & - & - & - \\
\hline Vibrio $\mathrm{sp}$. & GM2 & R. philippinarum & Morbihan Gulf, France & - & - & - \\
\hline Vibrio sp. & GM4 & R. philippinarum & Morbihan Gulf, France & + & - & + \\
\hline Vibrio sp. & $2 a-4$ & R. philippinarum & Sligo, Ireland & - & - & - \\
\hline Vibrio sp. & T9a-3a & R. philippinarum & Sligo, Ireland & - & - & - \\
\hline Vibrio sp. & GL1 & R. philippinarum & Glénan, France & - & - & \\
\hline Vibrio sp. & GL2 & R. philippinarum & Glénan, France & - & - & - \\
\hline Vibrio $\mathrm{sp}$. & GL4 & R. philippinarum & Glénan, France & - & - & - \\
\hline Vibrio sp. & GL5 & R. philippinarum & Glénan, France & - & - & - \\
\hline Vibrio sp. & GL6 & R. philippinarum & Glénan, France & - & - & - \\
\hline Vibrio sp. Rd S & RD0202 & R. decussatus & Galicia, Spain & nd & +++ & - \\
\hline V. tapetis $\mathrm{Rp} 29-\mathrm{a}$ & IS-1 & R. philippinarum & Landeda, France & +++ & +++ & +++ \\
\hline V. tapetis $\mathrm{Rp} 29$ & IS-5 & R. philippinarum & Landeda, France & +++ & +++ & +++ \\
\hline V. tapetis $\mathrm{Rp} 56$ & IS-7 & R. philippinarum & Quiberon, France & +++ & +++ & +++ \\
\hline V. tapetis Va 56 & IS-8 & V. aurea & Quiberon, France & +++ & +++ & +++ \\
\hline$V$. tapetis Ce 56 & IS-9 & C. edule & Quiberon, France & +++ & +++ & +++ \\
\hline V. tapetis $\mathrm{Rp} 29-\mathrm{b}$ & $29-b$ & R. philippinarum & Landeda, France & +++ & +++ & +++ \\
\hline V. tapetis Rpn 56 & P16b & R. philippinarum & Morbihan Gulf, France & +++ & +++ & +++ \\
\hline V. tapetis Rp UK & UK6 & R. philippinarum & United kingdom & +++ & +++ & +++ \\
\hline V. tapetis $\mathrm{Rp} 29$ & $\mathrm{P} 21$ & R. philippinarum & Bay of Brest, France & +++ & $\begin{array}{l}+++ \\
++\end{array}$ & +++ \\
\hline V. tapetis $\mathrm{Rd} \mathrm{S}$ & RD0705 & $R$. decussatus & Galicia, Spain & nd & +++ & +++ \\
\hline V. tapetis Rp S & RP1703 & R. philippinarum & Galicia, Spain & nd & +++ & +++ \\
\hline V. tapetis $\mathrm{Rp} \mathrm{S}$ & RP6301 & R. philippinarum & Galicia, Spain & nd & +++ & +++ \\
\hline V. tapetis $\operatorname{Rp} 29$ & 2.3 & R. philippinarum & Landeda, France & nd & +++ & +++ \\
\hline V. tapetis $\mathrm{Rp} 29$ & 8.17 & R. philippinarum & Landeda, France & nd & +++ & +++ \\
\hline V. tapetis $\mathrm{Rp} 29$ & 9.7 & R. philippinarum & Landeda, France & nd & +++ & +++ \\
\hline V. tapetis $\operatorname{Rp} 29$ & 11.2 & R. philippinarum & Landeda, France & nd & +++ & +++ \\
\hline V. tapetis Hh UK & HH6087 & H. hippoglossus & Scotland, UK & nd & +++ & +++ \\
\hline V. tapetis $\mathrm{Sm} \mathrm{NO}$ & LP2 & S. melops & Bergen, Norway & nd & +++ & +++ \\
\hline Halomonas sp. 33 & P9 & R. philippinarum & Marennes, France & + & - & + \\
\hline Pseudomonas aeruginosa & PAO1 & & Our collection & - & - & nd \\
\hline Escherichia coli DH5 & & & Our collection & - & - & nd \\
\hline Bacillus subtillis & & & Our collection & - & - & nd \\
\hline Lactococcus lactis sp lactis & & & Our collection & - & - & nd \\
\hline Enterococcus. faecalis & & & Our collection & - & - & nd \\
\hline Roseobacter sp. & X129 & Sea water & Portzic, France & - & - & nd \\
\hline
\end{tabular}




\begin{tabular}{|l|c|c|c|c|c|c|}
\hline Roseobacter galleaciensis & X34 & Collection & CIP 105210 & - & - & nd \\
\hline Roseobacter sp. & X20 & Sea water & Portzic, France & - & - & nd \\
\hline Roseobacter sp. & X6 & Sea water & Portzic, France & - & - & nd \\
\hline Vibrio sp. & DO1 & Sea water & Portzic, France & - & - & - \\
\hline Bacillus sp. & D02 & Sea water & Portzic, France & - & - & - \\
\hline Bacillus sp. & D22 & Sea water & Portzic, France & - & - & - \\
\hline Pseudoalteromonas sp. & D41a & Sea water & Portzic, France & - & - & - \\
\hline Pseudoalteromonas sp. & D41b & Sea water & Portzic, France & - & - & - \\
\hline Vibrio sp. & D66 & Sea water & Portzic, France & - & - & - \\
\hline
\end{tabular}

Table 3 : Genitor sampling at T0 and T30 and BRD diagnosis. n, number; \%, pourcentage of BRD and of clam survivors (in bold character); sam. , sampled.

\begin{tabular}{|c|c|c|c|c|c|c|c|c|c|c|c|c|c|c|c|}
\hline & \multicolumn{4}{|c|}{ T0 } & \multicolumn{10}{|c|}{ T30 } \\
\hline & & \multicolumn{2}{|c|}{ sampled } & \multirow{2}{*}{\begin{tabular}{|l|} 
no sam. \\
n \\
\end{tabular}} & \multirow{2}{*}{$\begin{array}{c}\text { Total } \\
\mathrm{n} \\
\end{array}$} & \multicolumn{2}{|c|}{ sam. T0-T30 } & \multirow{2}{*}{\multicolumn{2}{|c|}{$\frac{\text { sam. only T30 }}{\mathrm{n}}$}} & \multicolumn{2}{|c|}{ Total sam. T30 } & \multicolumn{2}{|c|}{ no sam.T30 } & \multicolumn{2}{|c|}{ Total Clam } \\
\hline & & $\mathrm{n}$ & $\%$ & & & $\mathrm{n}$ & $\%$ & & & $n$ & $\%$ & $n$ & $\%$ & $\mathrm{n}$ & $\%$ \\
\hline \multirow[t]{2}{*}{ Fluid sampling } & Clam used & 212 & & \begin{tabular}{|l|}
108 \\
\end{tabular} & 320 & 51 & & 13 & & 64 & & 166 & & 230 & \\
\hline & Asymptomatic & 111 & 99,11 & & & 8 & 15,69 & 12 & 92,31 & 20 & 31,25 & 92 & 55,76 & 112 & 48,91 \\
\hline \multirow{4}{*}{$\begin{array}{c}\text { BRD } \\
\text { DIAGNOSTIC }\end{array}$} & Diseased & 1 & 0,89 & & & 18 & 35,29 & & & 18 & 28,13 & 38 & 23,03 & 56 & 24,45 \\
\hline & Recovered & 0 & 0 & & & 25 & 49,02 & 1 & 7,69 & 26 & 19,70 & 35 & 21,21 & 61 & 26,64 \\
\hline & Total D+R & 0 & 0 & & & 43 & 84,31 & & & 44 & 68,75 & 73 & 44,24 & 117 & 51,09 \\
\hline & total & 112 & & & 112 & 51 & & 13 & & 64 & 100,00 & 165 & & 229 & \\
\hline \multirow[t]{2}{*}{ Fluid +BRD } & total & 112 & & & 112 & & & 13 & & 64 & & 165 & & 229 & \\
\hline & Total clam & 212 & & 108 & 320 & 51 & & 13 & & 64 & & 166 & & 230 & 71,875 \\
\hline
\end{tabular}


E. coli 60 AgTCGAACGGTAACAGGAAGAAGCTTGCT-357-GAGGAAGGGAGTAAAGTTAATACCTTTGCTCATTGACGTTA

V. tapetis 37 AgtCGAGCGGAAACGAGAAGTAGCTTGCT-358-GAGGAAGGGGTGTACGTTAATAGCGTGCATCCTTGACGTTA

Figure 1 

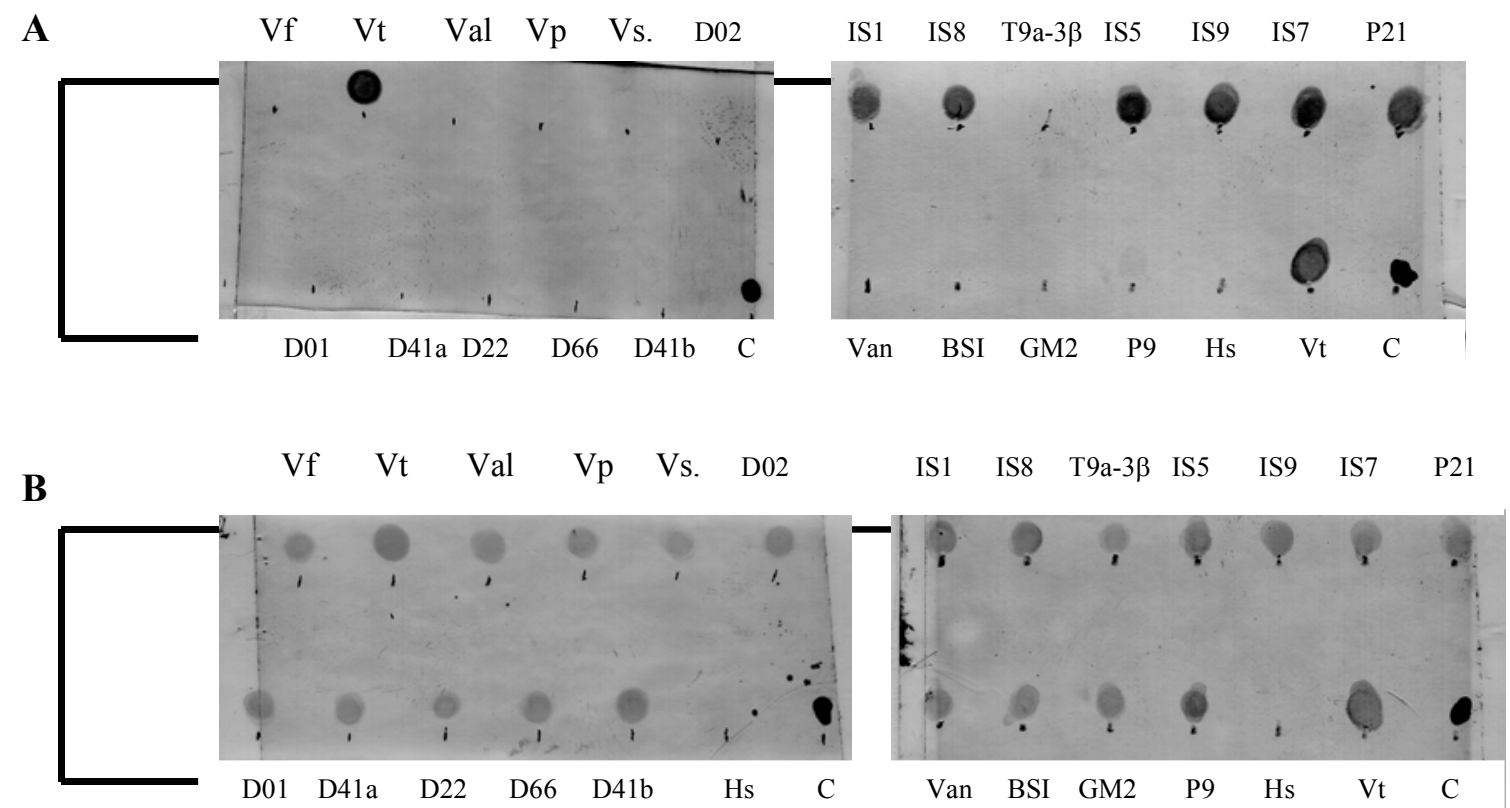

Figure 2

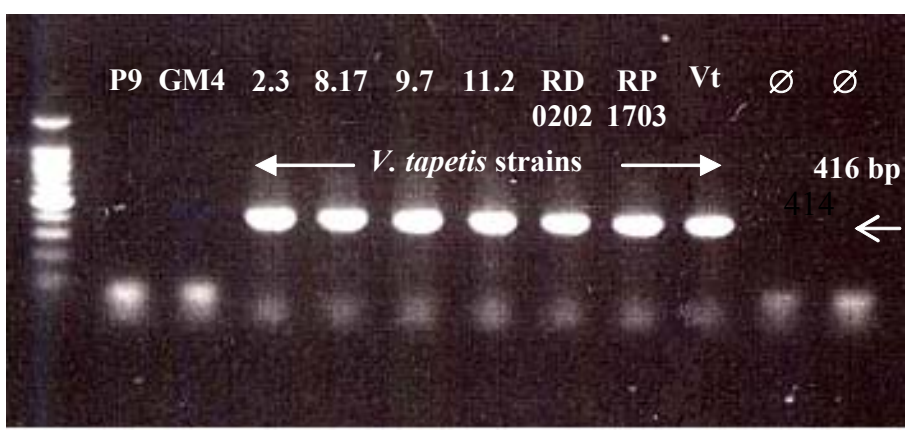

Figure 3 


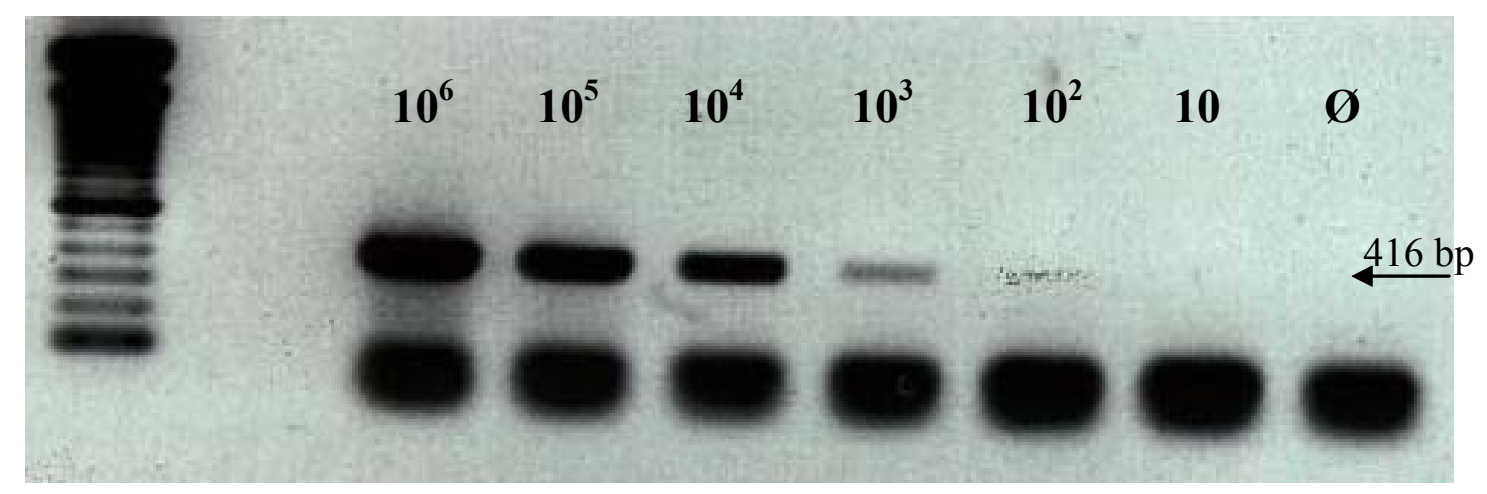

Figure 4

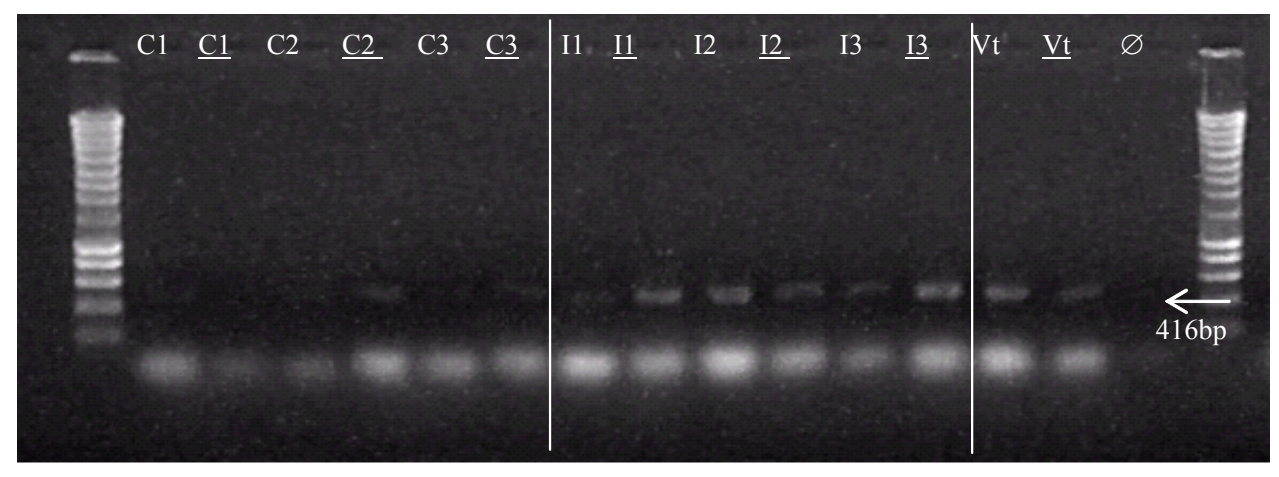

Figure 5 


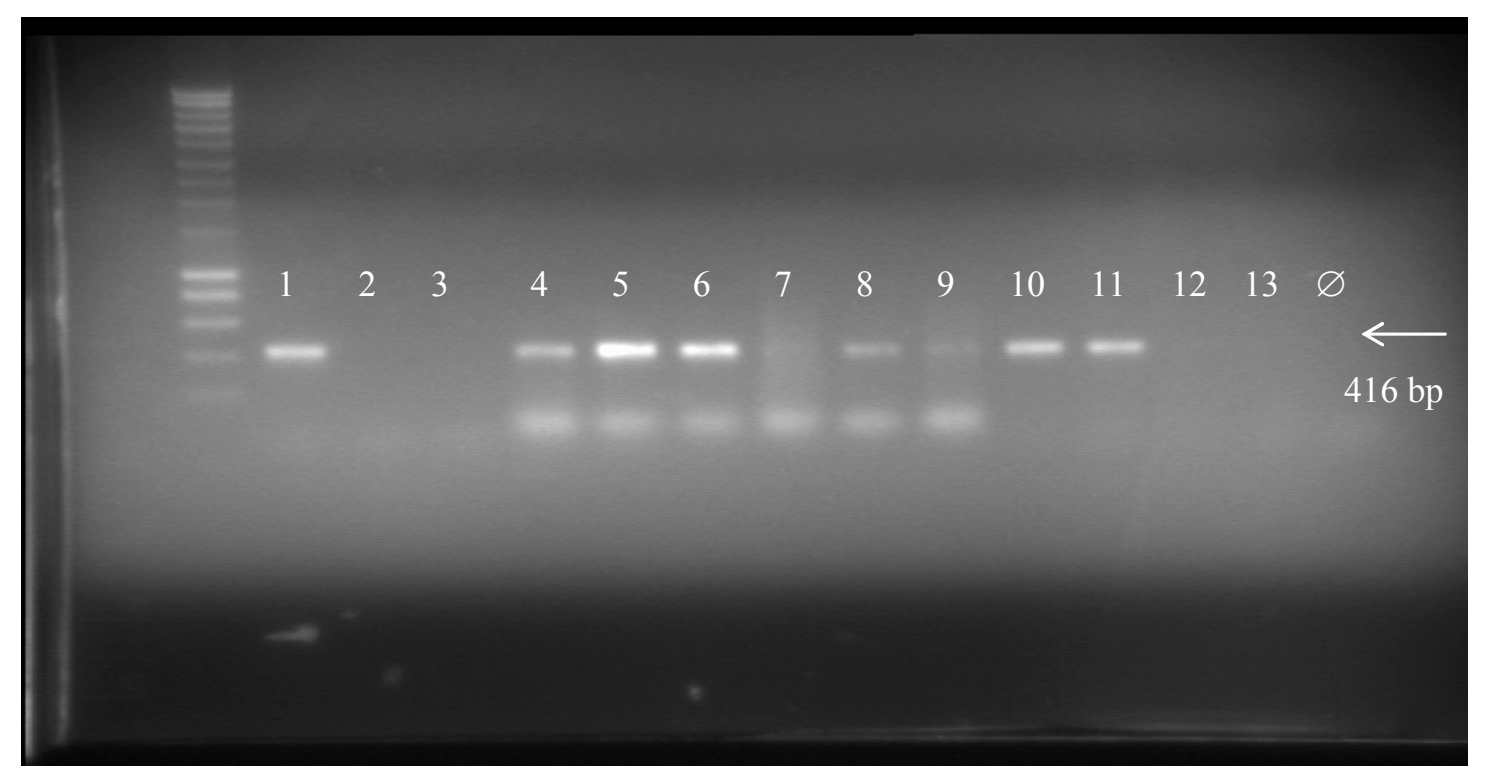

Figure 6 